\title{
Öğretmenlerin Yaratıcılığı Destekleme Durumları ile Öğrencilerin Yazma Özerkliklerinin İncelenmesi
}

\author{
Hasan Güner BERKANT \\ Yozgat Bozok Ünivesitesi Eğitim Fakültesi \\ h.guner.berkant@yobu.edu.tr \\ ORCID ID: 0000-0003-0725-6036 \\ Zeynep BURUN \\ Kahramanmaraş Sütçü İmam Üniversitesi \\ burunzey@gmail.com \\ ORCID ID: 0000-0002-1935-8761
}

\begin{tabular}{lrr} 
Araştırma Makalesi & DOI: $10.31592 /$ aeusbed.907610 \\
\hline Geliş Tarihi: 31.03 .2021 & Revize Tarihi: 23.06.2021 & Kabul Tarihi: 24.07.2021
\end{tabular}

\section{Atıf Bilgisi}

Berkant, H. G. ve Burun, Z. (2021). Öğretmenlerin yaratıcılığı destekleme durumları ile öğrencilerin yazma özerkliklerinin incelenmesi. Ahi Evran Üniversitesi Sosyal Bilimler Enstitüsü Dergisi, 7(2), 427-446.

\section{ÖZ}

$\mathrm{Bu}$ araştırmanın genel amacı, öğretmenlerin yaratıcılığı destekleme durumları ile öğrencilerin yazma özerkliklerini incelemektir. Araştırma ilişkisel tarama modelindedir. Araştırmanın çalışma evrenini, 20192020 eğitim-öğretim yılında Kahramanmaraş Onikişubat ilçesinde bulunan ortaokullarda görev yapan öğretmenler ve bu okullarda öğrenim gören ortaokul öğrencileri oluşturmaktadır. Araştırmanın örneklemini ise bu evrenden kolay ulaşılabilir örneklem yoluyla seçilen 50'si öğretmen, 281'i öğrenci toplam 331 kişi oluşturmaktadır. Araştırma verileri, "Yaratıcılığı Destekleyen Öğretmen İndeksi Ölçeği” ve "Yazma Özerkliği Ölçeği" kullanılarak toplanmıştır. Araştırma verilerinin analizinde, bağımsız gruplar t-testi, tek yönlü varyans analizi (ANOVA), Mann Whitney-U testi, Kruskal Wallis-H testi, Tukey anlamlllık testi ve Pearson korelasyon analizi kullanılmıştır. Araştırma sonucunda, ortaokul öğretmenlerinin yaratıcıllğı destekleme düzeylerinin yüksek olduğu belirlenmiștir. Ayrıca, ortaokul öğretmenlerinin cinsiyetinin, kıdemlerinin ve proje ödevi verme sıklıklarının öğretmenlerin yaratıcılığı desteklemeleri üzerinde genel olarak belirleyici bir etkiye sahip olmadığı tespit edilmiştir. Bunun yanı sıra, ortaokul öğrencilerinin yazma özerkliklerinin ortalamanın üzerinde olduğu tespit edilmiştir. Kız öğrencilerin yazma özerkliğinin erkek öğrencilerden daha yüksek olduğu sonucuna ulaşılmıştır. Öğretmenlerin yaratıcıllğı destekleme durumları ile öğrencilerin yazma özerkliklerinin düşük düzeyde de olsa aynı yönde değişim gösterebileceği sonucuna ulaşılmıştır.

Anahtar Kelimeler: Yaratıcılık, yaratıcılığı destekleme, yazma özerkliği, yazma becerisi, özerk öğrenme.

\section{Examination of Teachers' Creativity Fostering Levels and Students' Writing Autonomy}

\begin{abstract}
The main purpose of this research is to examine the creativity fostering levels of teachers and writing autonomy of their students. The research has used correlational survey desing. The population of the study consists of the teachers working at the secondary schools and the secondary school students studying at the schools in Onikişubat District of Kahramanmaraş Province during the 2019-2020 academic year. The sample of the study consists of 331 individuals; namely 50 teachers and 281 students chosen through convenience sampling among the above-mentioned population. The data of the study has been collected using "The Adaptation of Creativity Fostering Primary Teachers Index Scale into Turkish" and "Writing Autonomy Scale". For data analysis, independent samples t-test, one-way analysis of variance (ANOVA), Mann Whitney-U test, Kruskal Walis-H test, Tukey significance test and Pearson correlation analysis have been performed. According to results of the study, it has been reached that the creativity fostering levels of the secondary school teachers are high. In addition, it was determined that the gender, seniority and frequency of assigning project homework do not have a determining effect on teachers' support for creativity in general. It has also been observed that the writing autonomies of the secondary school students are over the average. It has also been concluded that writing autonomy of the female students is generally higher than the male ones' writing autonomies It has been concluded that the creativity fostering levels of the teachers and the writing autonomies of the students may vary at the same direction even at low levels.
\end{abstract}

Keywords: Creativity, fostering creativity, writing autonomy, writing skills, autonomous learning. 


\section{Giriş}

Öğrencinin merkezde olduğu, araştırdığı, sorduğu, merak ettiği, sorumluluk aldığı bir ortamda verilen eğitimle, öğrencilerin hem yaratıcılığını hem de özerkliğini destekleyecek eğitim ortamları oluşturulur (Durukan, 2008; Köksal, 2008). Medeniyetlerin ve toplumların gelişiminde önemli bir yere sahip olan yaratıcılık her bireyde var olan ve yaşamın her evresinde ortaya çıkabilen bir yetenek, tüm alanları içine alan bir tutum ve davranış şeklidir (Bacak, 2008). Torrance'a (2003) göre yaratıcılık; karşılaşılan zorlukları, sorunları, bilgi eksikliklerini algılamak ve bu eksikliklerle ilgili tahminlerde bulunmak, hipotez oluşturmak, bulunulan tahminleri, hipotezleri test etmek, gözden geçirmek ve sonuçları ilan etmektir. Yaratıcılık doğuştan gelen bir beceri değildir, aksine eğitim yoluyla yaratıcı bireyler yetiştirilebilir (Sternberg ve Lubart, 2016). Yaratıcı bireyler yetiştirebilmek için öncelikle bu bireylerin sahip olması gereken özelliklerin bilinmesi gerekir ve uygun öğrenme ortamları oluşturularak uygun öğretim yöntem ve teknikleri kullanılmalıdır (Korkmaz, 2018). Bu bağlamda bireyleri hayata hazırlayan eğitim kurumları ve öğretmenler, bireylerin yaratıcılığının dikkate alınması ve geliştirilmesi açısından önemlidir (Şahin, 2003). Öğrencilerin yaratıcılığının ortaya çıkmasında ve ilerlemesinde en önemli unsur öğretmenin öğrencilerine karşı gösterdiği tutum ve davranışlarıdır (Dikici, 2013). Bir öğrencinin yaratıcı olabilmesi ancak yaratıcı bir öğretmenle mümkün kılınabilir (Trnova, 2014).

Mesleğini gerçekten seven ve bunu öğrencilerine hissettiren, derste anlattığ öğrencilerinde heyecan ve merak uyandırabilen, sorduğu sorularla öğrencilerin hayal gücünü harekete geçirebilen, nazik ve sevecen tavırla öğrencilerine yaklaşabilen ve onları motive edici övgüler sunabilen öğretmenler yaratıcı bireyi destekleyen öğretmenler olarak adlandırılabilir (Öztürk, 2004). Dolayısıyla sınıf içerisindeki eğitim etkinlikleriyle ve kullanılan materyallerle öğretmenlerin, öğrencilerin yaratıcılığını desteklemesi önemli görülmektedir. Ayrıca sınıf ortamında özgür bırakılan öğrenci, eğitim etkinliklerinde kendini daha rahat ifade etme imkânı bulabilir. Bu durum öğrenci özerkliği kavramı ile açıklanabilir.

Holec, öğrenci özerkliğini bireyin kendi öğrenme sorumluluğunu alması olarak tanımlamış ve bu tanım alanyazında kabul görmüştür (Benson, 2006). Little (1995) da aynı şekilde öğrenci özerkliğinin temelini öğrencilerin kendi öğrenme sorumluluklarını almalarına bağlamış ve bu durumun öğrenciler üzerinde sosyo-duygusal, bilişsel etkilere katkı sağladığını ifade etmiştir. Özerk bireyler eylemlerini gerçekleştirirken seçimler yapabilen ve bağımsız olabilen bireylerdir (Littlewood, 1996). Özerklik desteği sağlayan öğretmenler, öğrencilerin kendi yöntemleriyle problemleri çözebilmeleri için gerekli olan bilgileri vererek onları cesaretlendirmelidir (Black ve Deci, 2000). Öğrencilerin ilgilerini, amaçlarını kendilerinin belirlemesine yardımcı olarak öğrenme sorumluklarını almalarına ve görevlerini üstlenmelerine imkân vermelidirler (Assor, Kaplan ve Roth, 2002). Öğrenciler sadece bilgi alıcısı olarak görülmemelidir. Aksine öğrencilerin keşif rolünü üstlenmeleri önemlidir, ancak başarılı olmaları için destek ve rehberliğe ihtiyaç vardır. Bunun için öğretmenlerin, özerkliği ve eğitimöğretim etkinliklerinde öğrenci merkezli olmayı teşvik etmenin yollarının ve araçlarının farkında olarak pedagojik bakımdan hazırlanması gerekir. Öğretmenler öğrencilerin ilgisini çekerek yaratıcı yaklaşımların geliştirilmesine olanak sağlar (Simplicio, 2000). Öğrencilerin yaratıcılıklarını ortaya çıkaran eğitim-öğretim etkinlikleri arasında yazma etkinlikleri dikkat çekmektedir.

Bireyin kendi iç dünyasında kurgulanan ve karmaşık bir yapıya sahip olan yazma becerisinde, öğrencinin bu süreçte kendi öğrenme sorumluluğunu alması, yönetim ve kontrol mekanizmasını kullanabilmesi, amaç, içerik ve yöntem gibi teknik konuları belirleyebilmesi, yani bu süreçte baştan sona kadar etkin rol alması önemlidir (Sügüumlü, 2016). Yazma becerisinin insanda bir ihtiyaç hâline gelmesini sağlayan en önemli etken yaratıcılıktır. Bireyin doğuştan getirdiği yaratıcılık yeteneğini ortaya çıkarmanın bir yolu da yazma becerisidir (Yaz, 2015). Yaratıcılık yazmanın zihinde yapılandırılmış ve ifade edilmeye hazır soyut boyutudur. Dil ise zihinde oluşan düşüncenin aktarılmasını sağlayan somut boyutu oluşturur. Bu iki boyut birbirini destekleyen, geliştiren ve tamamlayan niteliktedir. Yazma ürününün niteliği yaratıcıllğa bağlıdır (Temizkan, 2010). 
Yazma sürecinde, kendini motive eden ve özerk hisseden öğrenci zihnindeki yaratıcılı̆̆ 1 keşfedecek ve bunu yazıya dökme fırsatı bulabilecektir (Runco, 2003). Öğretmenlerin eğitim ortamlarında öğrencilerin yaratıcılığını desteklemesi, onları motive etmesi ile öğrencilerin yazma çalışmaları yaparken kendi öğrenme sorumluluğunu üstlenmesine ve yaratıcılıklarını ortaya çıkarmasına imkân vermektedir. Yaratıcılık ile yazma eylemi arasında oldukça sıkı bir bağ olduğu ifade edilebilir. Yazma özerkliği öğrencilerin yazma eylemini gerçekleştirirken bu süreçteki tüm sorumluluğu üstlenmeleri olarak ifade edilebilir. O hâlde öğrencinin yazma sürecinde metnin konusunu, yöntemini belirlerken özgür olması, bir başka deyişle kalıplaşmış kurallar içerisinde değil de kendi bilişsel süzgeçlerinden geçirerek bu eylemi gerçekleştirmesi yaratıcılığın bir göstergesi kabul edilebilir. Yazma sürecinde özerk olan öğrenci kendi özgün metinlerini ortaya çıkarmada daha başarılı olabilir. Özerklik yaratıcılığın kullanılmasına alan açarken yaratıcılık da yazma özerkliğini besleyen bir unsur olarak düşünülebilir. $\mathrm{Bu}$ nedenle öğretmenlerin yaratıcılı̆̆ 1 destekleme durumları ile öğrencilerin yazma özerklikleri arasındaki ilişki önem kazanmaktadır.

Yaratıcılığın desteklenmesi ile ilgili olarak ulaşılabilen alanyazın incelendiğinde; Aslan ve Arslan Cansever (2009) eğitimde yaratıcıllğın kullanımına ilişkin öğretmen tutumlarını incelemişlerdir. Çayırdağ (2017) yaratıcı öz-yeterlilik ve öğretmen etkinliği ile öğretmenlerin yaratıcılığı teşvik edici davranışları arasındaki bağlantıyı ortaya koymaya çalışmıştır. Batdal Karaduman ve Çiftçi (2018) ise sınıf öğretmenlerinin yaratıcılığı destekleme durumlarını farklı değişkenler açısından incelemişlerdir. Kaya (2018) Bilim Sanat Merkezi öğretmenlerinin yaratıcıllı̆̆ destekleme düzeylerini incelerken, Yıldız ve Baltacı (2018) devlet okullarında ve özel okullarda görev yapan ortaokul matematik öğretmenlerinin yaratıcıllğ çalışmışlardır. Fleith (2000), öğretmenlerin ve öğrencilerin sınıf ortamında yaratıcıllğın gelişimini uyaran veya engelleyen özellikler hakkındaki algılarını incelemiştir. Dababneh, Ihmeideh ve Al-Omari (2010) sınıfların yaratıcı ortamının gelişimini teşvik eden veya engelleyen öğretmenlerin sınıf içi uygulamalarını belirlemeye çalışmışlardır. Olawale, Adeniyi ve Olubela (2010) ise iki ayrı üniversitede görev yapmakta olan öğretim elemanlarının yaratıcılığı destekleme durumlarını belirlemeyi amaçlamışlardır. Wang ve Shan (2019) öğretmenlerin, yaratıcılığı teşvik eden davranışları ile bireysel yaratıcılıkları arasındaki ilişkilerini incelemişlerdir.

Yazma özerkliği ile ilgili ulaşılabilen alanyazın incelendiğinde; Aliweh (2011), eğitim fakültesinde öğrenim gören 30 öğrenci ile yapılan deneysel çalışmada, öğrencilerin yazma becerileri ve öğrenci özerkliklerini incelemiştir. Dion (2011) ise Kanadalı öğrencilerin L2 yazma stratejilerini kullanarak ikinci dilde yazma özerkliklerinin gelişimi araştırmıştır. Foroutan, Noordin ve Gani (2013) Malezyalı öğrencilerin weblogu kullanmalarının yazma özerkliği üzerindeki etkisini belirlemiştir. Sügümlü (2016) ise yazma becerisinde öğrenci özerkliğinin yazmaya yönelik tutum ve motivasyonla ilişkisini belirlemek ve yazma becerisine öğrenci özerkliği ile yeni bir bakış açısı kazandırmayı amaçlamıştır. Tekşan ve Sügümlü (2018), ortaokul öğrencilerinin yazma özerkliklerini belirlemek amacıyla geçerli ve güvenilir bir ölçek geliştirmeyi amaçlamışlardır. Yine Tekşan ve Sügümlü (2019), ortaokul öğrencilerinin yazma özerklik düzeylerini çeşitli değiş̧kenler açısından incelemişlerdir.

Yaratıcılığı destekleyen öğretmenlerle ilgili sınırlı sayıda rastlanan çalışmalar incelendiğinde, örneklemin sınıf öğretmenleri, öğretim elemanları, öğretmen adayları tarafından oluşturulduğu gözlenmektedir. Bu araştırmada ise örneklem olarak ortaokul öğretmenleri belirlenmiş ve bu bağlamda alanyazında çok fazla örneğe ulaşılamamıştır. Bunun yanı sıra, ortaokul öğretmenlerinin yaratıcıllı̆ı destekleme durumları ile ortaokul öğrencilerinin yazma özerklikleri arasındaki ilişkiyi belirlemek amacıyla bu iki konuyu bütünleştiren bir çalışmaya alanyazında rastlanmamıştır. Bu araştırmadan elde edilen verilerin, ortaokulda görev yapan öğretmenlerin yaratıcılığ ortaokulda öğrenim gören öğrencilerin yazma özerkliklerini nasıl etkilediğini belirlemesi bakımından önemli olduğu düşünülmektedir. Ayrıca öğrencilerin yazma özerkliklerinin gelişiminin belirlenmesi ve öğretmenlerin öğrencilerinin yaratıcılıklarını destekleyerek aynı zamanda özerkliklerini de artırmaları yönünde bir farkındalık oluşturması açısından önemli kabul edilebilir. Bu anlamda araştırma ortaokul öğretmenlerinin, yaratıcılı̆̆ 1 destekleme sürecinde hangi durumlarda öğrencileri teşvik ettikleri hangi durumlarda yetersiz kaldıklarının belirlenmesi açısından, öğretmenlere bir yol haritası göstermesi bakımından öneriler sunabilir. Ayrıca öğretmenlerin bu süreçte öğrencilerin yaratıcıllğına katkı 
sağlayacak hangi yöntem ve teknikleri kullanmaları gerektiği, yaratıcılık eğitiminde nelere dikkat edilmesi gerektiği ve kendi sorumlulukları hakkında bilgiler vererek bu konuda daha bilinçli eğitimöğretim ortamları oluşturulması bakımından önem arz etmektedir. Bu bağlamda çalışmanın problem cümlesi "Ortaokul öğretmenlerinin yaratıc1lığı destekleme durumları ile öğrencilerin yazma özerklikleri çeşitli değişkenlere ve aralarındaki ilişkiye göre nasıldır?” şeklinde ifade edilebilir.

\section{Araştırmanın Amacı}

$\mathrm{Bu}$ araştırmanın genel amacı, ortaokul öğretmenlerinin yaratıcılığı destekleme durumları ile ortaokul öğrencilerinin yazma özerkliklerini çeşitli değişkenlere ve aralarındaki ilişkiye göre incelemektir. Bu genel amaç doğrultusunda aşağıdaki sorulara yanıt aranmıştır:

1. Öğretmenlerin yaratıcılığı destekleme durumları;

a) Cinsiyetlerine göre,

b) Kıdemlerine göre,

c) Proje ödevi verme sıklığına göre anlamlı farklılık göstermekte midir?

2. Öğrencilerin yazma özerklikleri;

a) Cinsiyetlerine göre,

b) Sınıf düzeyine göre,

c) Okuma sıklığına göre,

d) Anne eğitim düzeyine göre,

e) Baba eğitim düzeyine göre anlamlı farklılık göstermekte midir?

3. Öğretmenlerin yaratıcılığ 1 destekleme durumları ile öğrencilerinin yazma özerkliği arasında anlamlı bir ilişski var mıdır?

\section{Yöntem}

Araştırmanın bu bölümünde araştırmanın modeli, evren ve örneklemi, veri toplama araçları, verilerin toplanması ve verilerin analizi ile bilgiler yer almaktadır.

\section{Araştırmanın Modeli}

Araştırmada betimsel tarama modellerinden ilişkisel tarama yöntemi kullanılmıştır. Tarama modelleri geçmişte ya da hâlen var olan bir durumu olduğu gibi betimlemeyi amaçlayan araştırmalardandır (Williams, 2007). İlişkisel tarama modelleri ise iki ya da daha fazla sayıdaki değişken arasında birlikte değişimin varlı̆̆ını ve derecesini belirleyen araştırma desenleridir (Karasar, 2009). Çalışmada kullanılan bağımlı değişkenler ortaokul öğretmenlerinin yaratıcılığı destekleme eğilimleri ile ortaokul öğrencilerinin yazma özerkliği eğilimleridir. Bağımsız değişkenler ise, öğretmenler için cinsiyet, kıdem ve proje ödevi verme sıklığı; öğrenciler içinse cinsiyet, sınıf düzeyi, okuma sıklığı, anne eğitim düzeyi ve baba eğitim düzeyi olarak belirlenmiştir. Belirlenen değişkenler, öğretmenler açısından yaratıcıllı̆̆ desteklemelerine, öğrenciler açısından ise yazma özerkliği eğilimlerine doğrudan ya da dolaylı olarak etki ettiği düşünüldüğü için çalışmada kullanılmıştır.

\section{Evren ve Örneklem}

$\mathrm{Bu}$ araştırmanın çalışma evrenini, 2019-2020 eğitim-öğretim yılında Kahramanmaraş Onikişubat ilçesinde bulunan ortaokullarda görev yapan öğretmenler ve bu okullarda öğrenim gören ortaokul ögrencileri oluşturmaktadır. Çalışmanın örneklemini ise çalışma evreninden kolay ulaşılabilir örneklem yoluyla seçilen 50'si öğretmen, 281'i öğrenci toplam 331 kişi oluşturmaktadır. Kolay ulaşılabilir veya elverişli örnekleme; tamamen mevcut olan, ulaşması hızlı ve kolay olan ögelere dayanır (Baltac1, 2018). Bu yöntem düşük maliyete sahip ancak zengin bilgiye ulaşmada yardımcı ve genellemeler yapmada kullanılabilecek bir yöntem olması bakımından (Yıldırım ve Şimşek, 2013) tercih edilmiştir.

Tablo 1'de araştırmaya katılan öğretmenlerin, Tablo 2'de araştırmaya katılan öğrencilerin demografik özelliklerine ilişkin verilerin dağılımı verilmiştir. 
Tablo 1

Ortaokul Öğretmenlerinin Demografik Özelliklerine İlişkin Elde Edilen Verilerin Dağılımı

\begin{tabular}{llll}
\hline Değişken & Gruplar & f & \% \\
\hline \multirow{2}{*}{ Cinsiyet } & Kadın & 25 & 50 \\
& Erkek & 25 & 50 \\
\hline \multirow{2}{*}{ Kıdem } & $5-16$ & 25 & 50 \\
& 17 ve üzeri & 25 & 50 \\
\multirow{2}{*}{ Proje Ödevi } & Dönemde bir & 42 & 84 \\
& Dönemde birkaç & 5 & 10 \\
& Hiç & 3 & 6 \\
\hline
\end{tabular}

Tablo 1'de görüldüğü gibi, örneklemi oluşturan öğretmenlerin cinsiyet ve kıdem değişkenlerinin eşit oranda olduğu, dönemde bir proje verenlerin oranının daha yüksek olduğu belirlenmiştir.

Tablo 2

Ortaokul Öğrencilerinin Demografik Özelliklerine İlişkin Elde Edilen Verilerin Dağılımı

\begin{tabular}{llll}
\hline \multicolumn{1}{c}{ Değişken } & Gruplar & f & \% \\
\hline \multirow{2}{*}{ Cinsiyet } & Kız & 127 & 45.2 \\
& Erkek & 154 & 54.8 \\
\hline \multirow{3}{*}{ Sınıf } & 5. sinıf & 81 & 28.8 \\
& 6. sınıf & 60 & 21.4 \\
& 7. sinıf & 65 & 23.1 \\
& 8. sınıf & 75 & 26.7 \\
\hline \multirow{3}{*}{ Okuma sıklığı } & Her gün & 174 & 61.9 \\
& Haftada birkaç saat & 92 & 32.7 \\
& Ayda birkaç saat & 7 & 2.5 \\
& Yılda birkaç saat & 4 & 1.4 \\
& Hiç & 4 & 1.4 \\
\hline \multirow{4}{*}{ Anne eğitim düzeyi } & Okumaz-yazmaz & 2 & 0.7 \\
& Sadece okuryazar & 5 & 1.8 \\
& İlkokul & 70 & 24.9 \\
& Ortaokul & 54 & 19.2 \\
& Lise & 90 & 32.0 \\
& Üniversite & 60 & 21.4 \\
\hline \multirow{3}{*}{ Baba eğitim düzeyi } & Okumaz-yazmaz & 1 & 0.4 \\
& Sadece okuryazar & 3 & 1.1 \\
& İlkokul & 35 & 12.5 \\
& Ortaokul & 41 & 14.6 \\
& Lise & 90 & 32.0 \\
& Üniversite & 111 & 39.5 \\
\hline
\end{tabular}

Tablo 2 incelendiğinde, örneklemi oluşturan öğrencilerin cinsiyet değişkeni açısından erkeklerin sayısının daha fazla olduğu, 5. sınıf düzeyinde olanların oranlarının daha yüksek olduğu, okuma sıklığı değişkeninde her gün okuyanların sayısının daha fazla olduğu, anne eğitim düzeyinde liseden mezun olanların oranının daha yüksek olduğu, baba eğitim düzeyinde ise üniversiteden mezun olanların oranının daha yüksek olduğu görülmektedir.

\section{Veri Toplama Araçları}

Araştırmada veri toplama aracı olarak "Kişisel Bilgi Formu", "Yaratıcıllı̆ı Destekleyen Öğretmen İndeksi Ölçeği” ve "Yazma Özerkliği Ölçeği” kullanılmıştır.

Ortaokul öğretmenlerinin cinsiyet, kıdem, proje ödevi verme sıklığı; ortaokul öğrencilerinin ise cinsiyet, sınıf düzeyi, okuma sıklığı, anne eğitim düzeyi ve baba eğitim düzeyi gibi bazı 
demografik özellikleri ile ilgili bilgi toplamak amacıyla araştırmacı tarafından geliştirilen öğrenciler ve öğretmenler için iki farklı "Kişisel Bilgi Formu" kullanılmıştır.

Soh (2000) tarafından geliştirilen ve Dikici (2013) tarafından Türkçeye uyarlanan "Yaratıcıllı̆g Destekleyen Öğretmen İndeksi Ölçeği (YDÖİÖ)" öğretmenlerin yaratıcılığı destekleyici sınıf içi davranışlarını ele alan 33 madde ve 9 alt boyuttan oluşmaktadır. Bu alt boyutlar bağımsızlık, bütünleştirme, güdüleme, yargilama, esneklik, değerlendirme, sorgulama, firsat verme ve hayal kırıklı̆̆ıdır. Ölçeğin derecelendirilmesi 5 (her zaman), 4 (sık sık), 3 (bazen), 2 (nadiren) ve 1 (hiçbir zaman) şeklinde düzenlenmiştir. Ölçekten alınabilecek en yüksek toplam puan 165 en düşük toplam puan ise 33 olarak belirlenmiştir. Ölçekte elde edilen toplam puan arttıkça öğretmenlerin de yaratıcılığı destekleme düzeyleri aynı oranda artmaktadır. Ölçekte ters puanlanan madde bulunmamaktadır. Dikici'nin (2013) yaptığ1 güvenirlik analizine göre, ölçekteki 33 maddenin tamamına ilişkin Cronbach Alpha katsayısı .94 iken, bağımsızlık, bütünleştirme, güdüleme, yargılama, esneklik, değerlendirme, sorgulama, firsat verme ve hayal kırıklığı alt boyutlarına ait katsayılar sırasıyla .64, .67, .77, .62, .69, .57, .71, .64, .75 şeklindedir. Bu çalışmanın verileri ile yeniden hesaplanan Cronbach Alpha değeri ölçeğin tümü için .89 olarak hesaplanmıştır. Bağımsızlık, bütünleştirme, güdüleme, yargılama, esneklik, değerlendirme, sorgulama, firsat verme ve hayal kırıklı̆gı alt boyutlarına ait Cronbach Alpha güvenirlik katsayıları sırasıyla .43, .54, .61, .57, .60, .63, $.58, .72, .74$ şeklindedir.

Ortaokul öğrencilerinin yazma özerkliklerinin belirlenmesi amacıyla "Yazma Özerkliği Ölçeği (YÖÖ)" uygulanmıştır. Araştırmada kullanılan, Tekşan ve Süğümlü (2019) tarafindan geliştirilen "YÖÖ", 22 maddeden oluşan ve üç alt boyutu olan bir ölçektir. Ölçeğin alt boyutları, motivasyon ve tutum, paylaşım ve değerlendirme, planlama ve süreçtir. Ölçekten elde edilen toplam puan arttıkça yazma özerklik düzeyi artmaktadır. Ölçek 3'lü likert tipinde olup 3 (evet), 2 (kısmen), 1 (hayır) seçeneklerinden oluşmaktadır. Ölçekte ters madde yer almamaktadır. Ölçekten alınabilecek en düşük puan 22, en yüksek puan 66'dır. Tekşan ve Sügü̈mlü (2019) tarafından ölçeğin tamamına ilişkin Cronbach Alpha katsayıs1 .82 olarak, motivasyon ve tutum alt boyutu .83, paylaşım ve değerlendirme alt boyutu .84 , planlama ve süreç alt boyutu ise .80 olarak hesaplanmıştır. Bu çalışmada elde edilen verilerle yeniden hesaplanan ölçeğin tamamına ilişkin güvenirlik katsayısının .89 olduğu belirlenmiştir. Motivasyon ve tutum, paylaşım ve değerlendirme, planlama ve süreç alt boyutlarının güvenirlik katsayıları ise sırasıyla $.82, .78, .81$ şeklindedir.

\section{Verilerin Toplanması ve Analizi}

Araştırmanın verileri 2019-2020 eğitim öğretim yılında Kahramanmaraş Onikişubat ilçesinde bulunan bir ortaokulda görev yapan öğretmenlerden ve bu öğretmenlerin öğrencilerden toplanmıştır. Kahramanmaraş İl Milli Eğitim Müdürlüğü'nden gerekli izinler alındıktan sonra veri toplama araçları araştırmacı tarafindan öğretmenlere ve öğrencilere bulundukları okulda dağıtılmış, gerekli açıklamalar yapıldıktan sonra doldurulması sağlanmıştır. Her bir form kontrol edilerek araştırmacı tarafindan toplanmıştır. Veriler araştırmacı tarafından kontrol edilerek bilgisayar ortamına aktarılmıştır. Bilgisayar ortamına aktarılan verilerin istatistiksel çözümlemeleri gerçekleştirilmiştir. İstatistiksel işlemlerin uygulanması sürecinde anlamlılık düzeyi .05 olarak kabul edilmiştir. Grupların varyans homojenliğini sağlayıp sağlamadığını test etmek amacıyla Levene testi yapılmıştır. Levene testi sonuçlarında anlamlı farkın çıkmasının yanı sıra, bir gruba düşen kişi sayısı 20'den az olması durumlarında da parametrik olmayan testler kullanılmıştır (Büyüköztürk, 2009). Kruskal Wallis-H testi ve bağımsız gruplar t-testi kullanılmıştır. Anlamlı farklılaşmanın tespiti durumunda Tukey anlamlılık çözümlemesi ve Mann Whitney-U testi yapılmıştır. Etki büyüklüğü hesaplamalarında parametrik testler için eta-kare $\left(\eta^{2}\right)$ istatistiği kullanılmıştır. Eta-kare .00 ile 1.00 arasında değer almaktadır. Sırasıyla, .01 düşük, .06 orta, .14 yüksek değer olarak yorumlanabilir (Büyüköztürk, 2009). Parametrik olmayan testlerde ise Cohen d değeri hesaplanmıştır. Cohen kriterlerine göre .1 düşük, .3 orta ve .5 yüksek değer olarak kabul edilir (Pallant, 2017). Ayrıca, öğretmenlerin yaratıcılığı destekleme durumları ile öğrencilerin yazma özerklikleri arasındaki ilişkinin belirlenmesinde, verilerin çarpıklık katsayılarının +1 ile -1 arasında değer aldığ (YDÖIÖ için .10, YÖÖ için -.76), bu nedenle normal dağılım gösterdiği belirlendiğinden Pearson Korelasyon analizi kullanılmıştır. Korelasyon 
analizinde 0 ila .30 arasındaki korelasyon değeri düşük, .31 ila .70 arasında orta ve .71 ila 1 arasında yüksek korelasyon olarak kabul edilmektedir (Büyüköztürk, 2009). Betimsel istatistiklerin değerlendirilmesinde, her bir bağımsız değişken kategorisinde YDÖİÖ'nün tamamına ve alt boyutlarına ait puanların ortalamasın 2.5 değerinde olması ortalama bir değer olarak kabul edilirken, YÖÖ'de ise 1.5 değerinde olması ortalama değer olarak kabul edilmiştir.

\section{Araştırma Etiği}

Veri toplama sürecinde katılımcılara dürüst davranılmıș ve katılımcıların kimlikleri gizli tutulmuştur. Veriler manipüle edilmeden analiz edilip tarafsılık ilkesine hassasiyet gösterilmiştir. Ayrıca Kahramanmaraş Sütçü İmam Üniversitesi Sosyal ve Beşeri Bilimleri Etik Kurulu (05/11/2019 tarihli ve 45386 sayılı) tarafından "Öğretmenlerin Yaratıcılığı Destekleme Durumları ile Öğrencilerin Yazma Özerkliklerinin İncelenmesi" adlı çalışmasında kullanılacak olan araçlar incelenmiş olup söz konusu araçların ilgili kişilere uygulanmasında Sosyal ve Beşeri Etik Kuralları ve İlkeleri çerçevesinde herhangi bir sakınca olmadığına karar verilmiştir.

\section{Bulgular}

$\mathrm{Bu}$ bölümde araştırmaya katılan öğretmenlerin yaratıcıllğı destekleme durumlarına ve araştırmaya katılan öğrencilerin yazma özerkliklerine yönelik bulgulara araştırmanın alt amaçları doğrultusunda yer verilmiştir.

\section{Ortaokul Öğretmenlerinin Yaratıcılığı Destekleme Durumlarına İlişkin Bulgular}

Ortaokul öğretmenlerinin, yaratıcılığı destekleyen öğretmen indeksi ölçeğinden aldıkları puanlara ilişkin betimsel istatistikler Tablo 3 'te sunulmuştur.

Tablo 3

Ortaokul Öğretmenlerinin Yaratıcıllğg Destekleme Durumlarına İlişkin Betimsel İstatistikler

\begin{tabular}{llll}
\hline Ölçek/Alt Boyutlar & $\mathbf{n}$ & $\overline{\boldsymbol{X}}$ & ss \\
\hline YDÖIÖO & 50 & 3.96 & 0.31 \\
Bağımsızlık & 50 & 4.34 & 0.55 \\
Bütünleştirme & 50 & 4.30 & 0.44 \\
Güdüleme & 50 & 4.56 & 0.43 \\
Yargılama & 50 & 3.86 & 0.54 \\
Esneklik & 50 & 4.21 & 0.48 \\
Değerlendirme & 50 & 3.86 & 0.65 \\
Sorgulama & 50 & 4.29 & 0.51 \\
Firsat verme & 50 & 4.28 & 0.48 \\
Hayal kırıklı̆̆ & 50 & 4.28 & 0.47 \\
\hline
\end{tabular}

Tablo 3 incelendiğinde, ortaokul öğretmenlerinin yaratıc1lı̆̆ destekleyen öğretmen indeksi ölçeğinden aldıkları toplam puanların aritmetik ortalaması 3.96'dır. Ölçek alt boyutlarından alınan toplam puanların aritmetik ortalamasının ise 3.86 ila 4.56 arasında değiştiği görülmektedir. $\mathrm{Bu}$ bulgulara göre ortaokul öğretmenlerinin yaratıcılığı destekleme durumları bakımından ölçeğin tamamında ve tüm alt boyutlarında ortalamanın üzerinde değer aldı ̆̆ ifade edilebilir. Alt boyutlardan elde edilen puanlar incelendiğinde öğretmenlerin en düşük puanları yargılama ve değerlendirme boyutunda aldıkları görülmektedir.

Ortaokul öğretmenlerinin yaratıcılığı destekleme durumlarının cinsiyet değişkenine göre anlamlı biçimde farklılaşıp farklılaşmadığını belirlemeden önce yapılan Levene testi sonucunda, öğretmenlerin yaratıcılığı destekleme durumlarına ait puan dağılımı varyanslarının homojen olduğunun $(\mathrm{F}=.006, \mathrm{p}>.05)$ belirlenmesinden dolayı yapılan bağımsız gruplar t-testinin sonuçları Tablo 4'te sunulmuştur. 
Tablo 4

Ortaokul Öğretmenlerinin Yaratıcılı̆̆ı Destekleme Durumlarının Cinsiyete Göre Bağımsız Gruplar ttesti Sonuçları

\begin{tabular}{llllllll}
\hline Ölçek & Cinsiyet & $\mathbf{n}$ & $\overline{\boldsymbol{X}}$ & Ss & $\mathbf{d}$ & $\mathbf{t}$ & $\mathbf{p}$ \\
\hline \multirow{2}{*}{ YDÖIÖO } & Erkek & 25 & 3.93 & 0.1 & \multirow{2}{*}{8} & \multirow{2}{*}{-.830} & \multirow{2}{*}{0.41} \\
& Kadın & 25 & 4.00 & 0.32 & & & \\
\hline
\end{tabular}

Tablo 4 incelendiğinde, katılımcıların yaratıcıllğı destekleyen öğretmen indeksi ölçeğinden aldıkları toplam puanların aritmetik ortalaması sırasıyla erkek öğretmenler için 3.93 ve kadın öğretmenler için 4.00 olarak belirlenmiştir. Ortaokul öğretmenlerinin yaratıcılığı destekleme durumlarının cinsiyete göre anlamlı şekilde farklılık göstermediği belirlenmiştir, t(48)=-.830, p>.05.

Ortaokul öğretmenlerinin yaratıcılığı destekleme durumlarının kıdem değişkenine göre anlamlı biçimde farklılaşıp farklılaşmadığını belirlemeden önce yapılan Levene testi sonucunda, öğretmenlerin yaratıcılığı destekleme durumlarına ait puan dağılımı varyanslarının homojen olduğunun $(\mathrm{F}=.468, \mathrm{p}>.05)$ belirlenmesinden dolayı yapılan bağımsız gruplar t-testinin sonuçları Tablo 5 'te sunulmuştur.

Tablo 5

Ortaokul Öğretmenlerinin Yaratıcılı̆̆ı Destekleme Durumlarının Kıdeme Göre Bağımsız Gruplar ttesti Sonuçları

\begin{tabular}{llllllll}
\hline Ölçek & Kıdem(yl) & $\mathbf{n}$ & $\overline{\boldsymbol{X}}$ & ss & sd & t & p \\
\hline \multirow{2}{*}{ YDÖİÖ } & 5-16 & 25 & 3.90 & 0.30 & \multirow{2}{*}{48} & -1.327 & \multirow{2}{*}{0.19} \\
& 17 ve üzeri & 25 & 4.02 & 0.32 & & & \\
\hline
\end{tabular}

Tablo 5'e göre katılımcıların yaratıcılı̆̆1 destekleyen öğretmen indeksi ölçeğinden aldıkları toplam puanların aritmetik ortalaması sırasıyla kıdemi 5-16 yıl arası olan öğretmen için 3.90 ve kıdemi 17 yıl ve üzeri olan öğretmenler için 4.02 olarak bulunmuştur. Ortaokul öğretmenlerinin yaratıcılığı destekleme durumlarının kıdeme göre anlamlı şekilde farklılık göstermediği tespit edilmiştir, $t(48)=$ $1.327, \mathrm{p}>.05$.

Ortaokul öğretmenlerinin yaratıcılığı destekleme durumlarının proje ödevi verme sıklığı değişkenine göre anlamlı farklılaşma olup olmadığını belirlemek için Kruskal Wallis-H testi yapılmıştır. Analiz sonuçları Tablo 6'da sunulmuştur.

Tablo 6

Ortaokul Öğretmenlerinin Yaratıcılı̆̆ı Destekleme Durumlarının Proje Ödevi Verme Sıklı̆ğna Göre Kruskal Wallis-H Testi Sonuçlart

\begin{tabular}{lllllll}
\hline ÖIçek & Proje Ödevi Verme Sıklı̆g & n & S.O & Sd & $\mathbf{X}^{\mathbf{2}}$ & p \\
\hline \multirow{3}{*}{ YDÖIÖO } & Hiç & 3 & 33.83 & 2 & 1.15 & 0.56 \\
& Dönemde bir & 5 & 25.21 & & & \\
& Dönemde birkaç & 42 & 22.90 & & & \\
& Toplam & 50 & & & & \\
\hline
\end{tabular}

Tablo 6 incelendiğinde, ortaokul öğretmenlerinin yaratıc1lığı destekleme durumlarının $\left(\mathrm{X}^{2}=1.15, \mathrm{p}>.05\right)$ proje ödevi verme sıklığına göre anlamlı olarak farklılaşmadığı tespit edilmiştir.

\section{Ortaokul Öğrencilerinin Yazma Özerkliklerine İlişkin Bulgular}

Ortaokul öğrencilerinin yazma özerkliklerini belirlemek amacıyla yazma özerkliği ölçeğinden alınan puanlara ilişkin betimsel istatistikler Tablo 7'de verilmiştir. 
Tablo 7

Ortaokul Öğrencilerinin Yazma Özerkliklerine İlişkin Betimsel İstatistikler

\begin{tabular}{llll}
\hline Ölçek/Alt Boyutlar & $\mathbf{n}$ & $\overline{\boldsymbol{X}}$ & ss \\
\hline YÖÖ & 281 & 2.23 & 0.41 \\
Motivasyon ve Tutum & 281 & 2.30 & 0.48 \\
Paylaşım ve değerlendirme & 281 & 2.06 & 0.50 \\
Planlama ve süreç & 281 & 2.36 & 0.53 \\
\hline
\end{tabular}

Tablo 7 incelendiğinde, ortaokul öğrencilerinin yazma özerkliği ölçeğinden aldıkları toplam puanların ortalaması 2.23 olarak hesaplanmıştır. Ölçek alt boyutlarından alınan toplam puanların aritmetik ortalamasının ise 2.06 ila 2.36 arasında değiştiği görülmektedir. Bu bulgulara göre ortaokul öğrencilerinin yazma özerklikleri bakımından ölçeğin tamamında ve tüm alt boyutlarında aldıkları puanların ortalamanın üzerinde olduğu ifade edilebilir. Alt boyutlardan elde edilen puanlar incelendiğinde, öğrencilerin en düşük puanı "paylaşım ve değerlendirme" boyutunda aldıkları görülmektedir.

Ortaokul öğrencilerinin yazma özerkliklerinin cinsiyet değişkenine göre anlamlı biçimde farklılaşıp farklılaşmadığını belirlemeden önce yapılan Levene testi sonucunda, öğrencilerin yazma özerkliklerine ait puan dağılımı varyanslarının homojen olduğunun ( $\mathrm{F}=3.668, \mathrm{p}>\quad .05)$ belirlenmesinden dolayı yapılan bağımsız gruplar t-testinin sonuçları Tablo 8 'de sunulmuştur.

Tablo 8

Ortaokul Öğrencilerinin Yazma Özerkliklerinin Cinsiyete Göre Bağımsız Gruplar t-testi Sonuçları

\begin{tabular}{lllllllll}
\hline Ölçek & Cinsiyet & $\mathbf{n}$ & $\overline{\boldsymbol{X}}$ & ss & sd & $\mathbf{t}$ & $\mathbf{p}$ & $\boldsymbol{\eta}^{2}$ \\
\hline \multirow{2}{*}{ YÖÖ } & Erkek & 154 & 2.17 & 0.44 & \multirow{2}{*}{279} & \multirow{2}{*}{-2.940} & \multirow{2}{*}{$0.00^{*}$} & \multirow{2}{*}{0.03} \\
& $\mathrm{~K}$ Kz & 127 & 2.31 & 0.35 & & & & \\
\hline
\end{tabular}

*p<.05

Tablo 8 incelendiğinde, yazma özerkliği ölçeğinde alınan toplam puanların cinsiyet değişkenine göre kız öğrenciler lehine istatistiksel olarak anlamlı farklılık oluşturduğu tespit edilmiştir, $\mathrm{t}(279)=-2.940, \mathrm{p}<.05$. Etki büyüklüğü dikkate alındığında yazma özerkliği ölçeğinde gözlenen varyansın \%1 ila \%3 oranında cinsiyete bağlı olduğu düşünülebilir. Dolayısıyla, cinsiyetin yazma özerkliğini düşük düzeyde etkilediği ifade edilebilir.

Ortaokul öğrencilerinin yazma özerklikleri arasında sınıf düzeyi değişkenine göre anlamlı farklılaşma olup olmadığını belirlemek için yapılan Kruskal Wallis-H testi sonuçları Tablo 9'da sunulmuş̧ur.

Tablo 9

Ortaokul Öğrencilerinin Yazma Özerkliklerinin Sınıf Düzeyine Göre Kruskal Wallis-H Testi Sonuçları

\begin{tabular}{lllllll}
\hline Ölçek & Sinıf & n & S.O & Sd & $\mathbf{X}^{\mathbf{2}}$ & $\mathbf{p}$ \\
\hline & 5 & 81 & 158.79 & 3 & 25.13 & $0.00^{*}$ \\
YÖÖ & 6 & 60 & 160.57 & & & \\
& 7 & 65 & 146.02 & & & \\
& 8 & 75 & 101.77 & & & \\
\hline
\end{tabular}

Tablo 9'da görüldüğü gibi, ortaokul öğrencilerinin yazma özerkliklerinin sınıf düzeyine göre anlamlı şekilde farklılaştığ belirlenmiştir, $\mathrm{X}^{2}=25.13, \mathrm{p}<.05$. Anlamlı farklılaşmanın hangi gruplar arasında olduğunu tespit etmek için yapılan Mann Whitney-U testi sonucunda, ortaokul öğrencilerinin yazma özerkliklerinin 5. ve 8. sinıflar arasında 5. sinıflar lehine (U=1824.000, p<.05), 6. ve 8. siniflar arasinda 6. siniflar lehine $(\mathrm{U}=1344.500, \mathrm{p}<.05)$, 7. ve 8. siniflar arasinda 7. siniflar lehine $(\mathrm{U}=1614.500, \mathrm{p}<.05)$ anlamlı farklılaştığı belirlenmiştir. Etki büyüklükleri dikkate alındığında yazma özerkliği ölçeğinde gözlenen varyansın \%29 ila \%34 oranında öğrenim görülen sınıf düzeyine bağlı 
olduğu düşünülebilir. Dolayısıyla, öğrenim görülen sınıf düzeyinin yazma özerkliği ölçeğinin toplam puanını orta düzeyde etkilediği düşünülebilir.

Ortaokul öğrencilerinin yazma özerkliklerinin okuma sıklıklarına göre anlamlı farklılaşıp farklılaşmadığını belirlemek için Kruskal Wallis-H testi yapılmıştır. Analiz sonuçları Tablo 10'da sunulmuştur.

Tablo 10

Ortaokul Öğrencilerinin Yazma Özerkliklerinin Okuma Slklıklarına Göre Kruskal Wallis-H Testi Sonuçlart

\begin{tabular}{lllllll}
\hline Ölçek & Okuma Sıklı̆̆ & $\mathbf{n}$ & S.O & Sd & $\mathbf{X}^{\mathbf{2}}$ & $\mathbf{p}$ \\
\hline & Her gün & 174 & 160.43 & 4 & 32.19 & $0.00^{*}$ \\
& Haftada birkaç saat & 92 & 116.93 & & & \\
YÖÖ & Ayda birkaç saat & 7 & 61.57 & & & \\
& Yılda birkaç saat & 4 & 83.13 & & & \\
& Hiç & 4 & 46.50 & & & \\
& Toplam & 281 & & & & \\
\hline
\end{tabular}

Tablo 10'da ortaokul öğrencilerinin yazma özerkliklerinin, okuma sıklı̆̆ına göre anlamlı farklılaşma olduğu tespit edilmiştir, $\mathrm{X}^{2}=32.19, \mathrm{p}<.05$. Anlamlı farklılaşmanın hangi gruplar arasında olduğunu tespit etmek için yapılan Mann Whitney-U testine ilişkin sonuçlar incelendiğinde, ortaokul öğrencilerinin yazma özerkliklerinin, ölçeğin genelinde her gün okuyanlarla haftada birkaç saat okuyanlar arasında her gün okuyanlar lehine $(\mathrm{U}=5488.000, \mathrm{p}<.05)$, her gün okuyanlarla ayda birkaç saat okuyanlar arasında her gün okuyanlar lehine $(\mathrm{U}=197.500, \mathrm{p}<.05)$, her gün okuyanlarla hiç okumayanlar arasında her gün okuyanlar lehine $(\mathrm{U}=86.000, \mathrm{p}<.05)$ haftada birkaç saat okuyanlarla ayda birkaç saat okuyanlar arasında haftada birkaç saat okuyanlar lehine $(U=175.500, p<.05)$, haftada birkaç saat okuyanlarla hiç okumayanlar arasında haftada birkaç saat okuyanlar lehine ( $\mathrm{U}=75.500$, $\mathrm{p}<.05)$ anlamlı farklılık olduğu tespit edilmiştir. Bunlar dışındaki ikili karşılaştırmalarda ise anlamlı fark bulunmamaktadır ( $>$.05). Etki büyüklükleri dikkate alındığında, yazma özerkliği ölçeğinin tamamında gözlenen varyansın \%19 ila \%25 oranında okuma sıklığına bağlı olduğu düşünülebilir. Dolayısıyla okuma sıklığının yazma özerkliğini düşük düzeyde etkilediği ifade edilebilir.

Ortaokul öğrencilerinin yazma özerkliklerinin anne eğitim düzeyine göre anlamlı farklılaşıp farklılaşmadığını belirlemek için Kruskal Wallis-H testi yapılmıştır. Analiz sonuçları Tablo 11'de verilmiştir.

Tablo 11

Ortaokul Öğrencilerinin Yazma Özerkliklerinin Anne Eğitim Düzeyine Göre Kruskal Wallis-H Testi Sonuçlart

\begin{tabular}{lllllll}
\hline Ölçek & Anne Eğitim Düzeyi & n & S.O & Sd & $\mathbf{X}^{\mathbf{2}}$ & p \\
\hline & Okumaz-Yazmaz & 2 & 176.50 & 5 & 4.18 & 0.52 \\
& Sadece okuryazar & 5 & 89.30 & & & \\
YÖÖ & Illkokul & 70 & 146.14 & & & \\
& Ortaokul & 54 & 144.81 & & & \\
& Lise & 90 & 144.88 & & & \\
& Üniversite & 60 & 129.47 & & & \\
& Toplam & 281 & & & & \\
\hline
\end{tabular}

Tablo 11'de görüldüğ̈̈ gibi, öğrencilerin yazma özerklikleri anne eğitim düzeyine göre anlamlı farkl111k göstermemektedir, $\mathrm{X}^{2}=4.18, \mathrm{p}>.05$. 
Ortaokul öğrencilerinin yazma özerkliklerinin baba eğitim düzeyine göre anlamlı farklılaşıp farklılaşmadığını belirlemek için yapılan Kruskal Wallis-H testi sonuçları Tablo 12'de verilmiştir.

Tablo 12

Ortaokul Öğrencilerinin Yazma Özerkliklerinin Baba Eğitim Düzeyine Göre Krukal Wallis-H Testi Sonuçlart

\begin{tabular}{lllllll}
\hline Ölçek & Baba Eğitim Düzeyi & n & S.O & Sd & $\mathbf{X}^{2}$ & p \\
\hline & Okumaz-yazmaz & 1 & 239.50 & 5 & 10.48 & 0.06 \\
& Sadece okuryazar & 3 & 8.83 & & & \\
YÖÖ & İlkokul & 35 & 148.84 & & & \\
& Ortaokul & 41 & 151.00 & & & \\
& Lise & 90 & 139.58 & & & \\
& Üniversite & 111 & 138.67 & & & \\
\hline
\end{tabular}

Tablo 12'de görüldüğü gibi, ortaokul öğrencilerinin yazma özerkliklerinin baba eğitim düzeyine göre istatistiksel olarak anlamlı farklılaşma olmadığı tespit edilmiştir, $X^{2}=10.48, p>.05$.

\section{Ortaokul Öğretmenlerinin Yaratıcılığı Destekleme Durumları İle Ortaokul Öğrencilerinin Yazma Özerklikleri Arasındaki İlişkinin Belirlenmesine İlişkin Bulgular}

Ortaokul öğretmenlerinin yaratıcılığı destekleme durumları ile ortaokul öğrencilerinin yazma özerklikleri arasındaki ilişkiye yönelik Pearson Korelasyon analizi sonuçları Tablo 13'te verilmiştir.

Tablo 13

Ortaokul Öğretmenlerinin Yaratıcılı̆̆ Destekleme Durumları ile Ortaokul Öğrencilerinin Yazma Özerklikleri Arasındaki İlişkiye Yönelik Sonuçlar

\begin{tabular}{lll}
\hline Ölçek & & Ölçek \\
\hline & & YÖÖ \\
YDÖÏÖ & Pearson R & .270 \\
& $\mathrm{p}$ & $.000^{*}$ \\
& $\mathrm{~N}$ & 281 \\
\hline
\end{tabular}

*p<.05

Tablo 13 incelendiğinde ortaokul öğretmenlerinin yaratıcılığı destekleme durumları ile öğrencilerin yazma özerklikleri arasında düşük düzeyde ve pozitif yönde anlamlı bir ilişki olduğu görülmektedir (Pearson $\mathrm{R}=.270, \mathrm{p}<.05$ ).

\section{Sonuç, Tartışma ve Öneriler}

Araştırmada ortaokul öğretmenlerinin yaratıc1lığı destekleme durumları ile öğrencilerinin yazma özerklikleri incelenmiştir. Öğretmenlerin yaratıcıllğı destekleme durumları çeşitli değişkenler bağlamında incelenmiştir. Çalışmada ortaokul öğretmenlerinin, yaratıcıllı̆̆ destekleme durumlarının ortalama değerden yüksek olduğu belirlenmiştir. $\mathrm{Bu}$ durum öğretmenlerin, öğrenci merkezli yaklaşımla eğitim-öğretim yaptıkları, yapılandırmacı yaklaşımı benimseyerek 21. yüzyıl yeterliliklerini öğrencilerine kazandırma amacıyla çalıştıkları şeklinde yorumlanabilir. Araştırmanın sonucuyla benzer nitelikte, İnel Ekici (2016) ve İlhan (2016), ortaokul öğretmenlerinin yaratıcıllı̆̆ destekleme durumlarını ve algılarını incelediği çalışmada, öğretmenlerin yaratıcılığı destekleme düzeylerinin yüksek olduğunu tespit etmiştir. Aynı şekilde, Kılıç (2017), Anadolu, fen, sosyal bilimler ve güzel sanatlar lisesinde görev yapan fizik, kimya ve biyoloji öğretmenleri ile yaptığı çalışmada öğretmenlerin, öğrencilerin yaratıcı düşünme becerilerini destekleme düzeylerinin orta ve yüksek düzeyde olduğunu belirtmiştir. Yıldız ve Baltacı (2018) iki farklı kurumda çalışan matematik öğretmenlerinin yaratıcılığı destekleme durumları hakkında yaptıkları çalışmanın sonucunda, kolejde çalışan öğretmenlerin devlet okulunda çalışan öğretmenlere göre esneklik, değerlendirme, sorgulama, fırsat verme ve hayal kırıklığı boyutlarında daha yüksek düzeyde destekleyici olduğunu ifade etmiştir. 
Benzer şekilde, Kaya (2018) üstün yetenekli öğrencilerin öğretmenleriyle yaptığı çalışmada, öğretmenlerin yaratıcılığı destekleme düzeylerinin yüksek olduğunu saptamıştır. Batdal Karaduman ve Çiftçi'nin (2018) sınıf öğretmenlerinin yaratıcılığı destekleyici davranışları hakkında yaptıkları çalışmada sınıf içi eğitim öğretim sürecinde öğretmenlerin yüksek düzeyde destekleyici olduğu sonucuna ulaşılmıştır.

Ortaokul öğretmenlerinin yaratıcıllğı destekleme durumlarının cinsiyet değişkeninden etkilenmediği belirlenmiştir. Bunun nedeni, kadın ya da erkek fark etmeksizin tüm öğretmenlerin, ezberci ve geleneksel eğitimden vazgeçip öğrencinin aktif olduğu bir eğitim-öğretim sürecini benimsemiş olması olabilir. Alanyazında bu sonuçla benzerlik gösteren çalışmalar mevcuttur (Batdal Karaduman ve Çiftçi, 2018; İnel Ekici, 2016; Kaya, 2018; Kılıç, 2017; Yenilmez ve Yolcu, 2007). Aynı şekilde, Çağ Adıgüzel (2006), sınıf öğretmenlerinin, öğrencilerin yaratıcı düşünme becerilerini destekleme durumlarının cinsiyetlerine göre anlamlı fark göstermediği sonucuna ulaşmıştır. Fakat İlhan (2016), ilk ve ortaokullarda görev yapan öğretmenlerle yaptığı çalışmada, kadın öğretmenlerin yaratıcıllğ̆ destekleme düzeylerinin erkek ögretmenlere göre daha yüksek olduğunu tespit etmiştir.

Çalışmada ortaokul öğretmenlerinin yaratıcılığı destekleme durumlarının, kıdem değişkeninden etkilenmediği belirlenmiştir. Kıdemi 5-16 yıl arasında olan öğretmenlerin 2005 sonras1 güncellenen öğretim programları ile yapılandırmacı yaklaşıma göre öğretmenlik eğitimi aldığı, bu nedenle yaratıcılığı destekleme düzeylerinin yüksek olduğu düşünülebilir. Ancak kıdemi 17 yıl ve üzeri olan öğretmenlerin lisans eğitimlerinin geleneksel eğitim yaklaşımına yönelik olmasına rağmen yaratıcılık düzeylerinin yüksek olması, öğretmenlerin hizmet içi eğitimlerle yeni öğretim yaklaşımları ve yaratıcılık gibi konularda eğitim almalarıyla ilgili olabilir. Alanyazında bu sonuç ile benzerlik gösteren farklı çalışmalar yer almaktadır (İlhan, 2016; Kaya, 2018; Özel ve Bayındır, 2015). Benzer biçimde Çağ Adıgüzel (2016) yaptığı çalışmada sınıf öğretmenlerinin öğrencilerin yaratıcı düşünme becerilerini destekleyen davranışlarını incelemiş ve kıdeme göre anlamlı fark olmadığını tespit etmiştir. Fakat Yenilmez ve Yolcu (2007) öğretmen davranışların yaratıcı düşünme becerilerine etkisine yönelik araştırmalarında 1-10 yıl arası kıdeme sahip öğretmenlerin yaratıcı düşünme becerilerinin gelişimine daha çok katkılarının olduğu sonucuna ulaşmışlardır.

Çalışmada ortaokul öğretmenlerinin yaratıcılığı destekleme durumlarının proje ödevi verme sıklığından etkilenmediği sonucuna ulaşılmıştır. Bu durum öğretmenlerin öğrencilerinin yaratıcılığını desteklemek için farklı yöntem ve teknikleri kullanmalarıyla açıklanabilir. Benzer şekilde, Batdal Karaduman ve Çiftçi (2018) yaptı̆̆ çalışmada öğretmenlerin eğitim teknolojileri kullanım sıklıklarının yaratıcılığı destekleme düzeylerini anlamlı şekilde etkilemediği sonucuna ulaşmışlardır. Oysa Işık (2013) yaptığı çalışmada, yaratıcılığı geliştirmek için öğretmenlerin öğrenme ortamlarındaki uyaranları düzenlemeleri, beyni hazırlamaları, yaratıcı yöntem ve teknikleri kullanmaları gerektiği sonucuna ulaşmıştır. Ersoy ve Anagün (2009) 5. sınıf öğretmenleri ile yaptıkları çalışmada, öğretmenlerin fen ve teknoloji dersinde verdikleri proje ödevlerinin ne amaçla verildiğini araştırmışlar ve sonuç olarak, öğrencilerde sorumluluk bilincini kazandırmak ve yaratıcılığ geliştirmek gibi nedenlerle proje ödevi verildiğini belirtmiş̧lerdir. Proje ve performans ödevlerine ilişkin öğretmen görüşlerinin incelendiği bir çalışmada, öğretmenler proje ödevlerinin öğrencilerin yaratıcılığını geliştirdiği yönünde görüş bildirdikleri ifade edilmiştir (Bozkurt, Aslanargun, Akın ve Kılıç, 2014). Çek Cumhuriyeti'nde 25 ortaokul öğretmeni ile yapılan çalışmada, araştırma-incelemeye dayalı öğretim stratejisi kullanılarak yapılan fen öğretiminin öğretmenlerde ve öğrencilerde yaratıcılığ geliştirdiği sonucuna ulaşılmıştır (Trnova, 2014).

Araştırmada ortaokul öğrencilerinin yazma özerklikleri çeşitli değişkenler açısından incelenmiştir. Çalışma kapsamında öğrencilerin yazma özerkliklerinin ortalamanın üzerinde olduğu belirlenmiştir. Bunun nedeni, öğrencilerin yazma özerkliklerini destekleyen ev, okul ve sınıf ortamında bulunmaları olabilir. Buna benzer bir çalışmada Tekşan ve Sügümlü (2019) ortaokul öğrencilerinin yazma özerklik düzeylerinin orta seviyede olduğu sonucuna ulaşmıştır. Yine Sügümlü (2016) ortaokul öğrencileri ile yaptığı çalışmada, öğrencilerinin yazma eğitimini öğrenci özerkliği temellinde gerçekleştirmiş ve sonuç olarak öğrencilerin yazma becerilerinin olumlu yönde geliştiğini tespit etmiştir. Foroutan, Noordin ve Gani (2013) yaptıkları çalışmada, öğrencilerin yazma 
özerkliklerinin blog uygulamalarıyla geliştirilebildiği sonucuna ulaşmışlardır. Özellikle dil eğitiminde kullanılan ve öğrencilerin kendi sorumluluklarını üstlenerek yaptıkları yazma çalışmalarıyla özerkliklerini geliştirdikleri ve daha iyi öğrendikleri ifade edilmiştir. Dion (2011) Kanada'da yaptığ1 çalışmada öğrencilerin L2 yazma stratejilerini kullanarak ikinci dilde yazma özerkliklerinin gelişimini incelemiş ve öğrencilerin daha yetkin, bağımsız, sorumlulukları üstlenen, özerk ve verimli birer yazar olduğunu ifade etmiştir. Öğrencilerin yazı günlükleri tutarak yazma ile ilgili düşüncelerini denetlediği ve L2 yazma stratejileriyle özerklik bilinçlerinin geliştiği sonucuna ulaşılmıştır. Daskalogiannaki'nin (2012) Yunanistan'daki ortaokul öğrencileri ile yaptığı çalışmada, yazmayı öğretmek ve değerlendirmek için blog kullanımının öğrencileri daha özerk, yetkin ve eleştirel birer yazar olmalarına katkı sağladığı ve yazmaya karşı motive ettiği sonucuna ulaşılmıştır.

Araştırmaya katılan ortaokul öğrencilerinin yazma özerklikleri cinsiyet değişkenine göre incelenmiş ve ölçeğin genelinde, kız öğrencilerin yazma özerkliklerinin erkek öğrencilere kıyasla daha yüksek olduğu belirlenmiştir. Bunun nedeni, kız öğrencilerin duygu ve düşüncelerini yazılı olarak ifade etmeye ve paylaşmaya daha istekli olması olabilir. Ancak Tekşan ve Süğümlü (2019) yaptığ1 çalışmada öğrencilerin yazma özerkliğinin sadece "planlama ve süreç" alt boyutunda kız öğrenciler lehine anlamlı farklılık olduğunu tespit etmişlerdir. Sügü̈mlü (2016) öğrencilerin yazmaya karş1 motivasyon ve tutumlarını incelediği çalışmada, bu çalışmanın sonucundan farklı olarak, cinsiyetin öğrencilerin yazma yönelik tutumlarını etkilemediği sonucuna ulaşmıştır.

Ortaokul öğrencilerinin yazma özerklikleri sınıf düzeyine göre analiz edildiğinde, 5, 6 ve 7 . sınıf öğrencilerinin 8. sınıf öğrencilerine kıyasla daha fazla yazma özerkliğine sahip olduğu sonucuna ulaşılmıştır. Bu sonuç, 8. sınıf öğrencilerinin liseye geçiş sınavına hazırlanmaları ve bu nedenle çoktan seçmeli soru çözümü ve akademik başarı ile ilgili olmalarından kaynaklanabilir. Çalışmanın sonucunu destekler şekilde Tekşan ve Süğümlü de (2019) 5. sınıf öğrencilerinin yazma özerkliklerinin 6, 7 ve 8. sınıf öğrencilerinden yüksek olduğunu tespit etmiştir. Ancak Baş ve Şahin (2013) öğrencilerin yazma eğilimlerini inceledikleri çalışmada sınıf düzeyinin öğrencilerin yazma eğilimlerini etkilemediği sonucuna ulaşmıştır.

Ortaokul öğrencilerinin yazma özerklikleri okuma sıklığı değişkenine göre incelendiğinde, her gün okuyan öğrencilerin, haftada birkaç saat okuyan, ayda birkaç saat okuyan ve hiç okumayan öğrencilere kıyasla daha fazla yazma özerkliğine sahip olduğu belirlenmiştir. Bunun nedeni okuma ile yazma eylemi arasındaki döngüsel ilişki ile yorumlanabilir. Gümüş (2012) yaratıcı yazarlık derslerinde, yazma eyleminin ilk ve olmazsa olmaz basamağının okuma eylemi olduğunu, okumayla sürekli ve yoğun bir ilişki içerisinde olan kişinin yazmayı da er geç başaracağını belirtmiştir. Öğrencilerin yazma becerileri, okumayı alışkanlık hâline getirmeleri ve okuduklarından anlamlar çıkararak duygu ve düşüncelerini yazmaya çalışmaları ile gelişebilir (Baş ve Şahin, 2012). Çalışmanın sonucunu destekler biçimde Tok, Rachim ve Kuş (2014) ortaokul öğrencileriyle yaptıkları çalışmada, okuma alışkanlığı kazanmış ögrencilerin yazma eğilimi gösterdiği sonucuna ulaşmıştır.

Araştırmaya katılan ortaokul öğrencilerinin yazma özerkliklerinin anne ve baba eğitim düzeyinden etkilenmediği belirlenmiştir. Bu sonuç, anne ve babaların çocuklarına karşı sergiledikleri destekleyici tutumla açıklanabilir. Çalışmanın sonucunu destekler biçimde, Süğ̈ümlü (2016) yaptığı çalışmada öğrencilerin özerkliklerinin, yazmaya karşı tutumlarının ve motivasyonlarının anne ve baba eğitim düzeyine göre farklılık göstermediği sonucuna ulaşmıştır. Ortaöğretim öğrencilerinin yaratıcı yazma becerileri üzerinde yaptığı çalışmada, Karakuş Aktan (2013) öğrencilerin yaratıcı yazmalarının anne ve baba eğitim düzeyine göre değişmediği sonucuna ulaşmıştır. Tüfekçioğlu da (2010) ortaokul 6. sınıf öğrencilerinin yazma başarılarını ve yazma eğilimlerini incelediği çalışmada, öğrencilerin kompozisyon yazma başarılarının ebeveynlerinin eğitim düzeyine göre anlamlı farklılık göstermediğini ifade etmiş, ancak annesi lise ve yükseköğretim mezunu olanların yazma eğilimi algılarının annesi ilkokul mezunu olan öğrencilerden daha yüksek olduğunu belirtmiştir. Araştırmanın sonucundan farklı olarak, Baş ve Şahin (2013) yaptıkları çalışmada, öğrencilerin yazma eğilimlerinin anne eğitim durumu lise ve yükseköğretim olanlar lehine anlamlı farklılık tespit etmişlerdir. Coşkun (2006) da öğrencilerin anne ve baba eğitim durumlarının yükseköğretim olmasının onların kompozisyon yazmalarını olumlu etkilediği sonucuna ulaşmıştır. Başkan (2018) ortaokul yedinci sınıf 
öğrencilerinin yazma becerileriyle ilgili yaptı̆̆ çalışmada, öğrencilerin yazma becerilerinin anne ve baba eğitim durumuna göre anlamlı farklılık gösterdiğini belirlemiştir. Annesi ve babası ortaokul mezunu öğrenciler ile lise veya üniversite mezunu olan öğrencilerin yazma becerisinin, annesi ve babası okuryazar olmayan öğrencilere göre daha yüksek olduğu tespit edilmiştir.

Çalışmadan elde edilen sonuçlar ışığında uygulayıcılara ve araştırmacılara yönelik olarak aşağıdaki öneriler ileri sürülebilir:

- Bu araştırmada, ortaokul öğretmenlerinin yaratıcılığı destekleme düzeylerinin yüksek olduğu sonucuna ulaşılmıştır. Ancak "yargılama" ve "değerlendirme" alt boyutlarındaki toplam puanları diğer alt boyutlara göre daha düşük değer aldığından; öğretmenlerin, öğrencilerinin çalışmalarını değerlendirmesi konusunda alternatif değerlendirme yaklaşımlarını daha sık kullanmaları faydalı olabilir.

- Bu araştırmada, ortaokul öğrencilerinin yazma özerkliklerinin ortalamanın üzerinde olduğu sonucuna ulaşılmıştır. Ancak "paylaşım ve değerlendirme" alt boyutundaki toplam puan diğer alt boyutlara göre daha düşük değer aldığından, öğrenciler yazdıkları metinleri akranlarıyla ve öğretmenleriyle paylaşmaları yönünde teşvik edilebilir. Bunun için sınıf içi ya da okul içi etkinlikler düzenlenebilir.

- Ortaokul öğrencilerinin yazma özerkliklerinin cinsiyet değişkeninden etkilendiği, kız öğrencilerin yazma özerkliklerinin erkek öğrencilerden yüksek olduğu belirlenmiştir. Erkek öğrencilerin yazma özerkliklerinin desteklenmesi için ilgilerini çekebilecek konularda yazma çalışmaları yapmaları tavsiye edilebilir.

- Ortaokul öğrencilerinin yazma özerkliklerinin 5, 6 ve 7. sınıf düzeyinde yüksek iken 8. sınıf düzeyinde düşük olduğu sonucuna ulaşılmıştır. Lise geçiş sınavının öğrencilerin yazma özerkliğini olumsuz etkilediği düşünüldügünden, sınav sistemi öğrencinin özerkliğini destekleyecek şekilde düzenlenebilir.

- Ortaokul öğrencilerinin yazma özerkliklerinin okuma sıklığı değişkeninden etkilendiği, her gün okuyan öğrencilerin yazma özerkliklerinin daha yüksek olduğu sonucuna ulaşılmıştır. Eğitim durumları düzenlenirken öğrencilerin yazma özerkliklerinin okuma alışkanlığıyla ilişkisi dikkate alınarak okuma alışkanlığı kazandırmaya yönelik ders planları hazırlanabilir. Öğrencileri okumaya teşvik edici sınıf içi ve dışı etkinlikler düzenlenebilir.

- Bu araştırmada, ortaokul öğretmenlerinin yaratıcılığı destekleme durumları ile öğrencilerin yazma özerklikleri arasında aynı yönde pozitif bir ilişki olduğu sonucuna ulaşılmıştır. Öğretmenlere, yaratıcıllğı destekleyen öğretim yöntem ve tekniklerini derslerinde kullanmalarına paralel olarak öğrencilerin yaratıcılığının ve yazma özerkliklerinin de artabileceği yönünde farkındalık ve beceri eğitimleri verilebilir.

- $\mathrm{Bu}$ araştırma ortaokul öğretmenlerinin yaratıcılığ destekleme durumları ile ortaokul öğrencilerinin yazma özerkliklerini incelemek amacıyla yapılmıştır. Farklı çalışmalarda ilköğretim kademesinden başlayarak farklı örneklem gruplarının yaratıcılığı destekleme durumları ve yazma özerklikleri beraberce incelenebilir. Ayrıca, öğrencilerin yazma özerklikleri ile okuma alışkanlıklarının ilişkisi incelenebilir.

- Araştırmada nicel araştırma yöntemleri kullanılmıştır. İleride yapılacak çalışmalarda, ortaokul öğretmenlerinin yaratıcılığı destekleme durumları ile ortaokul öğrencilerinin yazma özerklikleri nitel araştırma yöntemlerinden (gözlem, görüşme, doküman incelemesi) yararlanılarak incelenebilir.

- Ulaşılabilen alanyazında, yazma özerkliği ile ilgili kısıtlı sayıda çalışmaya rastlanmıştır. Bu bakımdan, yazma özerkliğiyle ilgili alanyazını zenginleștirecek nitel ve nicel yöntemlere dayalı çalışmalar planlanabilir.

Açıklamalar: $\mathrm{Bu}$ çalışma, ikinci yazarın birinci yazar danışmalığında tamamladığı yüksek lisans tezinden üretilmiştir.

\section{Araştırmacıların Katkı Oranı}

Bu makaleye birinci yazarın $\% 50$, ikinci yazarın $\% 50$ oranında katkısı vardır. 


\section{Çıkar Çatışması}

$\mathrm{Bu}$ çalışmada çıkar çatışması teşkil edebilecek bir durum yoktur.

\section{Kaynaklar}

Aliweh, A. M. (2011). The effect of electronic portfolios on promoting Egyptian EFL college students' writing competence and autonomy. Asian EFL Journal, 13(2), 90-132.

Aslan, N. ve Arslan Cansever, B. (2009). Eğitimde yaratıcılığın kullanımına ilişkin öğretmen tutumları. Türk Bilim Araştırmaları Vakfi (TÜBAV) Bilim Dergisi, 2(3), 333-340.

Assor, A., Kaplan, H. and Roth, G. (2002). Choice is good, but relevance is excellent: Autonomy enhancing and suppressing teacher behaviours predicting students' engagement in schoolwork. British Journal of Educational Psychology, 72, 261-278.

Bacak, S. (2008). İlköğretim beşinci sınıf sosyal bilgiler dersinde öykü tabanlı öğrenme yaklaşımı ögrenenlerin akademik başarı ve yaratıcılıklarına etkisi. Yüksek lisans tezi. Celal Bayar Üniversitesi Sosyal Bilimler Enstitüsü, Manisa.

Baltacı, A. (2018). Nitel araştırmalarda örnekleme yöntemleri ve örnek hacmi sorunsalı üzerine kavramsal bir inceleme. Bitlis Eren Üniversitesi Sosyal Bilimler Enstitüsü Dergisi, 7(1), 231274.

Baş, G. ve Şahin, C. (2012). İlköğretim öğrencilerinin okuma tutumları, yazma eğilimleri ile Türkçe dersindeki akademik başarıları arasındaki ilişki. Turkish Studies, 7(3), 555-572.

Baş, G. ve Şahin, C. (2013). İlköğretim öğrencilerinin yazma eğilimlerinin farklı değişkenler açısından incelenmesi. Sakarya University Journal of Education, 3(1), 32-42.

Başkan, A. (2018). Kelime ve dilbilgisi düzeyinin yedinci sinıf öğrencilerinde yazma becerisi ile ilişkisi. Doktora tezi. İnönü Üniversitesi, Eğitim Bilimleri Enstitüsü, Malatya.

Batdal Karaduman, G. ve Çiftci, C. (2018). Sınıf öğretmenlerinin yaratıcılığı destekleyici davranışlarının incelenmesi. Sakarya University Journal of Education, 8(3), 242-262.

Benson, P. (2006). Autonomy in language teaching and learning. Language Teaching, 40, 21-40.

Black, A. E. ve Deci, E. L. (2000). The effescts of in structors' autonomy support and students' autonomous motivation on learning organic chemistry: A self determination theory perspective. Science Education, 84, 740-756.

Bozkurt, S., Aslanargun, E., Akın, S. ve Kılıç, A. (2014). İlköğretimde uygulanan proje ve performans ödevlerine ilişkin sınıf öğretmenlerinin görüşleri. Pamukkale Üniversitesi Sosyal Bilimler Enstitüsü Dergisi, 18, 157-173.

Büyüköztürk, Ş. (2009). Sosyal bilimler için veri analizi el kitabı. Ankara: Pegem Akademi.

Coşkun, İ. (2006). İlköğretim 5. sinıf ögrencilerinin kompozisyon yazma becerileri üzerine bir araştırma. Yüksek lisans tezi. Marmara Üniversitesi Eğitim Bilimleri Enstitüsü, İstanbul. 
Çă̆ Adıgüzel, D. (2016). Sinıf öğretmenlerinin yaratıcı düşünme becerileri ile öğretmen davranışlarının ögrencilerin yaratıcı düşünme becerilerinin gelişimine katkısı arasındaki iliş̧ki. Yüksek lisans tezi. Pamukkale Üniversitesi Eğitim Bilimleri Enstitüsü, Denizli.

Çayırdağ, N. (2017). Creativity fostering teaching: Impact of creative self-efficacy and teacher efficacy. Kuram ve Uygulamada Eğitim Bilimleri, 17(6), 1959-1975.

Dababneh, K., Ihmeideh, F. M. and Al-Omari, A. A. (2010). Promoting kindergarten children creativity in the classroom environment in Jordan. Early Child Development and Care, 108(9), $1165-1184$.

Daskalogiannaki, E. (2012). Developing and assessing EFL students' writing skills via class blog. Research Papers in Language Teaching and Learning, 3(1), 269-292.

Demir, T. (2013). İlköğretim öğrencilerinin yaratıcı yazma becerileri ile yazma özyeterlik algıs1 ilişkisi üzerine bir çalışma. Uluslararası Türkçe Edebiyat Kültür Ĕ̌itim Dergisi, 2(1), 84-114.

Dikici, A. (2013). Yaratıcılığı destekleyen ilköğretim öğretmenleri indeksi ölçeğinin Türkçeye uyarlanması. Kuram ve Uygulamada Ĕgitim Bilimleri, 13(1), 307-324.

Dion, C. M. (2011). Tools to enhance second language writing autonomy: Can we do things better? In D. Gardner (Ed.), Fostering autonomy in language learning (pp. 64-74).

Durukan, E. (2008). İlköğretim ikinci kademe (2005) Türkçe dersi öğretim programında genel amaçlar-hedef/kazanımlar ilişkisi. Uluslararası Sosyal Araştırmalar Dergisi-The Journal of International Social Research, 1(4), 149-158.

Ersoy, A. ve Anagün, Ş. S. (2009). Sınıf öğretmenlerinin fen ve teknoloji dersi ödev sürecine ilişkin görüşleri. Necatibey Eğitim Fakültesi Elektronik Fen ve Matematik Eğitim Dergisi, 3(1), 5879.

Fleith, S. D. (2000). Teacher and student perceptions of creativity in the classroom environment. Roeper Review, 22(3), 148-153.

Foroutan, M., Noordin, N. and Gani, M. S. (2013). Weblog promotes ESL learners' writing autonomy. Journal of Language Teaching and Research, 4(5), 994-1002.

Gümüş, S. (2012). Yazar olabilir miyim? Yaratıcı yazarlık dersleri. İstanbul: Notos Kitap.

Işık, D. A. (2013). Sınıf öğretmenlerinin yaratıcı bireyler yetiştirmede görev ve sorumlulukları. International Journal of Social Science, 6(6), 585-601.

İlhan, Z. (2016). Öğretmenlerin kullandıkları disiplin stilleri ile yaratıcıll̆ğ destekleyen ögretmen davranışları arasındaki ilişkinin incelenmesi. Yüksek lisans tezi. Niğde Üniversitesi Eğitim Bilimleri Enstitüsü, Niğde.

İnel Ekici, D. (2016). Öğretmenler öğrenme ortamında öğrencilerin yaratıcıllğını destekleme düzeylerine ilişkin kendilerini nasıl değerlendiriyorlar. International Periodical for the Languages, Literature and History of Turkish or Turkic, 11(3), 1287-1308.

Karakuş Aktan, E. N. (2013). Ortaöğretim öğrencilerinin yaratıcı yazma becerileri üzerine bir araştırma (Kütahya ili örneği). Adlyaman Üniversitesi Sosyal Bilimler Enstitüsü Dergisi Türkçenin Ĕ̈itimi Öğretimi Özel Sayısı, 6(11), 701-732.

Karasar, N. (2009). Bilimsel araştırma yöntemi. İstanbul: Nobel Yayın Dağıtım. 
Kaya, N. G. (2018). Üstün yetenekli öğrencilerin öğretmenlerinin yaratıcıllğı destekleme düzeylerinin belirlenmesi. Türk Ĕ̈itim Bilimleri Dergisi, 16(2), 157-175.

Kılıç, A. F. (2017). Öğretmenlerin yaratıcı düşünceyi destekleme davranışlarının incelenmesi. Adyaman University Journal of Educational Sciences, 7(1), 87-115.

Korkmaz, G. E. (2018). Yaratıcı düşünme ve günlük ders planı örneği. H. G. Berkant (Ed.), Düşünme Ĕgitimi (219-235). Çanakkale: Paradigma Akademi Yayınları.

Köksal, N. (2008). Eğitim programları ve yaratıcı drama. Yaratıcı Drama Dergisi, 1(3/4), 179-191.

Little, D. (1995). Learning as dialogue: The dependence of learner autonomy on teacher autonomy. System, 23(2), 175-181.

Littlewood, W. (1996). Autonomy in Communication and Learning in the Asian Context. Proceedings of the International, Conference Autonomy 2000: The Development Learning Indepence in Language Learning (124-140). Bangkok, Thailand KMITT. http://arts.kmutt.ac.th/dral/img/Autonomy2000.pdf\#page=133 adresinden 11.10.2019 tarihinde erişilmiştir.

Olawale, S. G., Adeniyi, E. O. and Olubela, O. I. (2010). Creativity fostering behaviour as an index of productivity and capacity building among lecturers in selected universities in Ogun and Oyo states. Educational Research and Reviews, 5, 257-262.

Özel, A. ve Bayındır, N. (2015). Sınıf öğretmenlerinin öğrencilerde yaratıcıllı̆̆ geliştirmeye yönelik öğretimsel davranışları. Uluslararası Türk Eğitim Bilimleri Dergisi, 3(5), 348-358.

Öztürk, Ş. (2004). Eğitimde yaratıcı düşünme. Ondokuz Mayıs Üniversitesi Eğitim Fakültesi Dergisi, $18,77-84$.

Pallant, J. (2017). SPSS kullanma kılavuzu: SPSS ile adım adım veri analizi. (çev. S. Balcı ve B. Ahi). Ankara: Anı Yayıncilik.

Runco, M. A. (2003). Education for creative potential. Scandinavian Journal Educational Research, 47(3), 317-324.

Simplicio, J. S. C. (2000). Teaching classroom educators how to be more effective and creative teachers. Education, 120(4), 675-680.

Soh, K. (2000). Indexing creativity fostering teacher behavior: A preliminary validation study. Journal of Creative Behavior, 34(2), 118-134.

Sternberg, R. J. and Lubart, T. I. (2016). Yaratıcı zihinler geliştirmek. A. C. Ornstein, E.F. Pajak ve S. B. Ornstein (Ed.), Eğitim Programlarında Güncel Sorunlar (132-142). (Çev. N. T. Bümen, Ö. Uslu, E. Ç. Özkan). Ankara: Pegem Akademi Yayınları.

Süğ̈̈mlü, Ü. (2016). Yazma becerisinde ögrrenci özerkliğinin yazmaya yönelik tutum ve motivasyonla ilişsisi: Bir eylem araştırması. Doktora tezi. Sakarya Üniversitesi Eğitim Bilimleri Enstitüsü, Sakarya.

Şahin, Ç. (2003). Değişen dünyada sınıf öğretmenlerinin değişen toplumsal ve yaratıcılık rolleri. Hacettepe Üniversitesi Sosyal Bilimler Enstitüsü Dergisi, 1(1), 1-9. 
Tekşan, K. ve Süğümlü, Ü. (2018). Yazma özerkliği ölçeği: Geçerlik ve güvenirlik çalışmas1. Uluslararası Türkçe Edebiyat Kültür Eğitim (TEKE) Dergisi, 7(4), 2591-2607.

Tekşan, K. ve Sügümlü, Ü. (2019). Ortaokul öğrencilerinin yazma özerkliği düzeylerinin çeşitli değişkenler açısından incelenmesi. Dil Dergisi, 170(1), 108-126.

Temizkan, M. (2010). Türkçe öğretiminde yaratıcı yazma becerilerinin geliştirilmesi. Türklük Bilimi Araştırmalarl, 27, 621-643.

Tok, M., Rachim, S. ve Kuş, A. (2014). Yazma alışkanlığı kazanmış öğrencilerin yazma nedenlerinin incelenmesi. Gazi üniversitesi Gazi Ë̆itim Fakültesi Dergisi, 34(2), 267-292.

Torrance, E. P. (2003). The millenium: A time for looking forward and looking back. The Journal of Secondary Gifted Education, 15(1), 6-12.

Trnova, E. (2014). IBSE and creativity development. Science Education International, 25(1), 8-18.

Tüfekçioğlu, B. (2010). Yazma becerisinin bazı değişkenler açısından incelenmesi. Dil Dergisi, 149, $30-45$.

Wang, W. ve Shan, J. (2019). A Preliminary Investigation into Creativity Fostering Behaviors of Maker Teachers in Shanghai. In K. Graziano (Ed.), Proceedings of Society for Information Technology \& Teacher Education International Conference (pp.1432-1437). Las Vegas, NV, United States: Association for the Advancement of Computing in Education (AACE). https://www.learntechlib.org/primary/p/207834/_adresinden 06.02.2020 tarihinde erişilmiştir.

Williams, C. (2007). Research methods. Journal of Business \& Economic Research, 5(3), 65-72.

Yaz, E. (2015). Yazma becerisinin gereksinim haline dönüşmesini sağlayan etkenler ve bu gereksinimin Türk edebiyatından örneklerle değerlendirilmesi. Yüksek lisans tezi. İstanbul Üniversitesi Eğitim Bilimleri Enstitüsü, İstanbul.

Yenilmez, K. ve Yolcu, B. (2007). Öğretmen davranışlarının yaratıcı düşünme becerilerinin gelişimine katkısı. Sosyal Bilimler Dergisi, 18, 95-105.

Yıldırım, A. ve Şimşek, H. (2013). Sosyal bilimlerde nitel araştırma yöntemleri. Ankara: Seçkin Yayınc1lı.

Yıldız, A. ve Baltacı, S. (2018). İki farklı kurumda çalışan ortaokul matematik öğretmenlerinin yaratıcılığı destekleme durumlarının incelenmesi. YYÜ Ĕ̆itim Fakültesi Dergisi, 15(1), 1392-1418. 


\section{Extended Abstract}

\section{Introduction}

One of the most important factors, which make writing skill a need for people, is creativity. A way for detection of the natural creativity of the individual is writing skill. Such a case has been observed for ages first on the wall paintings and then with the written works after the invention of writing (Yaz, 2015). Creativity is mainly the ability to use imagination and to see the details within a whole and the whole in the details. Appropriate environments must be provided at schools in order to reveal such ability of the students. Creativity may be revealed through different ways throughout life. This may happen sometimes via a painting or sculpture, sometimes with a literary text, and sometimes with a creative movie. At school environment, however, the most concrete reflection of the creativity skills of the students is the texts written by the students via their writing skills. For this reason, creativity and writing skills are very close to each other (Demir, 2013). The most important factors for revealing and improving the creativity skills of the students are the attitudes and behaviors of the teachers against the students (Dikici, 2013). A student's creativity is only possible with a creative teacher (Trnova, 2014). Writing autonomy may be described as assumption of the whole responsibility by a student during writing. Then, it may be supposed that a student's freedom to determine the subject and method of the text during the writing process, in other words his/her ability about writing by using cognitive process instead of stereotyped rules is an indicator of creativity.

\section{Method}

In this study, correlational survey model, which is one of the descriptive survey models, is used. The dependent variables used in this study are creativity fostering tendencies of the secondary school teachers and the writing autonomy tendencies of the secondary school students. Independent variables of teachers are gender, seniority, and frequency of assigning project paper. Students' independent variables are gender, class level, reading frequency, education level of their parents. The population of the study consists of the teachers working at the secondary schools and the secondary school students studying at the same schools in Onikişubat District of Kahramanmaraş Province during the 2019-2020 academic year. The sample of the study consists of 50 teachers and 281 students chosen through convenience sampling method among the above-mentioned population. "Personal Information Form", "Creativity Fostering Teachers Index Scale" and "Writing Autonomy Scale" have been used in the study. Creativity fostering teacher behavior index scale developed by Soh (2003) and adapted to Turkish by Dikici (2013) consists of 33 items and 9 sub-dimensions focusing on teachers' behaviors fostering creativity. "Writing Autonomy Index" has been used in order to determine the writing autonomies of the secondary school students. This index, which is developed by Tekşan and Süğümlü (2019) consists of 22 items and three sub-dimensions.

\section{Conclusion, Discussions and Recommendations}

Creativity fostering status of the teachers and writing autonomy of the students have been analyzed in this study according to some variables. It has been determined that the creativity fostering status of the secondary school teachers are over the average value. Similar to the result of the study, İnel Ekici (2016) and İlhan (2016) detected that the creativity fostering status and perceptions of the secondary school teachers are high. It has been showed that creativity fostering status is not affected by gender. There are studies supporting the result of this study in literature (Batdal Karaduman and Çiftçi, 2018; İnel Ekici, 2016; Kaya, 2018; K1lı̧, 2017; Yenilmez and Yolcu, 2007). However, İlhan (2016) declared in his study focusing on the teachers working at primary and secondary schools that creativity fostering level of the female teachers are higher than that of the male teachers. It is found in this study that creativity fostering status of the secondary school teachers is not affected by the seniority variable. Literature contains various studies supporting the result of this study (Illhan, 2016; Kaya, 2018; Özel \& Bayındır, 2015). It is concluded that creativity fostering status of the secondary school teachers is not affected by the frequency of assignment of project papers. A study realized by 
Bozkurt, Aslanargun, Akın and Kılıç (2014) showed that the teachers believed in the effectiveness of projects on increasing the students' creativity.

It has been observed within the scope of the study that the writing autonomy of the students is higher than the average. Tekşan and Sügümlü (2019) concluded in a study that the writing autonomy of the secondary school teachers is at average level. Writing autonomy of the secondary school students contained within the scope of the study has been analyzed according to the gender variable and it has been observed that the writing autonomy level of the female students is higher than that of the male students. However, Tekşan and Sügümlü (2019) determined in their study that writing autonomy of the students show significant difference in favor of the female students only in the context of "planning and process" sub-dimension. It has been determined that the writing autonomy level of the $5^{\text {th }}, 6^{\text {th }}$, and $7^{\text {th }}$ grade students are higher than that of the $8^{\text {th }}$ grade students. Tekşan and Sügüumlü (2019) observed in their study that the writing autonomy level of the $5^{\text {th }}$ grade students is higher than that of the $6^{\text {th }}, 7^{\text {th }}$, and $8^{\text {th }}$ grade students. It has been observed upon analysis of the reading frequency of the students that the students who read every day have higher writing autonomy level compared to the students who read a few hours a week, a few hours a month, and the students never reading. It has been detected that the writing autonomy level of the secondary school teachers contained within the scope of this study is not affected by the education level of the parents. Sügümlü (2016) concluded in a study conducted that the writing autonomy of the students as well as their attitudes and motivation towards writing does not differ according to the education level of the parents. Karakuş Aktan (2013) concluded in a study conducted on the creative writing skills of the secondary school students that creative writing status of the students does not differ according to the education level of the parents.

It has been concluded as a result of this study that there is positive correlation between the creativity fostering status of the secondary school teachers and the writing autonomy of their students. The teachers may be given awareness raising and skill improvement trainings in parallel with their usage of creativity fostering teaching methods and techniques during their lessons. Limited numbers of studies have been found on writing autonomy in literature during performance of this study. In this respect, studies focusing on qualitative and quantitative methods to enrich the relevant literature may be planned in connection with writing autonomy. 